\title{
Resiliensi komunitas di tengah pandemi Covid-19
}

\author{
Sunarno $^{(1)}$, Endang Sulistyowati ${ }^{(2)}$ \\ ${ }^{(1),(2)}$ Fakultas Ushuluddin dan Dakwah, Institut Agama Islam Negeri (IAIN) Kediri, Kediri, \\ Indonesia
}

Values and behaviours denote cultural strengths that help communities effectively adapt and succeed in dealing with disasters. The present work used a qualitative approach and was designed as a case study, to identify social values and behaviours in the context of community resilience during the Covid-19 pandemic. We recruited five informants and obtained data through interviews and observation. The results showed that community resilience emerged from a sense of belonging to the group (i.e., the residents) and its members. The residents have inherited social values and behaviours that have long lived in the community, which render them resilient against the Covid-19 pandemic. Such values include cooperation, deliberation, and harmony with nature, whereas the social behaviours manifest in obedience and prosocial neighbourhood. The implication of these findings is a hope that the residents can build community resilience. The residents may initiate such joint effort from the hamlet or village environment where they can build community resilience by developing social values and behaviours that grow in the community.

Keywords: community resilience, sense of belonging, social behaviour

Masyarakat memiliki kekuatan budaya berupa nilai-nilai dan perilaku yang berfungsi secara efektif untuk beradaptasi dan berhasil dalam menghadapi bencana. Penelitian ini menggunakan pendekatan kualitatif dan didesain sebagai studi kasus, dengan tujuan mengidentifikasi nilai dan perilaku sosial dalam konteks resiliensi komunitas di tengah pandemi Covid-19. Responden adalah lima informan dan data diperoleh melalui wawancara dan observasi. Hasil penelitian menunjukkan bahwa resiliensi komunitas bersumber dari rasa memiliki terhadap kelompok (yaitu warga lokal) dan anggota di dalamnya. Para warga lokal mewarisi nilai-nilai dan perilaku-perilaku sosial yang sudah sejak lama hidup di dalam masyarakat, yang membuat mereka mampu bertahan di masa pandemi Covid-19. Nilai-nilai tersebut mencakup nilai gotong royong, musyawarah, dan keselarasan dengan alam, sementara bentuk-bentuk perilaku sosial mencakup kepatuhan dan ketetanggaan yang prososial. Implikasi dari temuan-temuan tersebut adalah harapan bahwa warga lokal bisa membangun resiliensi komunitas. Warga lokal bisa mengawali upaya bersama tersebut dari lingkungan dusun ataupun desa dimana mereka membangun resiliensi dengan mengembangkan nilai-nilai dan perilaku-perilaku sosial yang tumbuh dalam masyarakat.

Kata kunci: perilaku sosial, rasa memiliki, resiliensi komunitas

MEDIAPSI, 2021, Vol. 7(1), 37-52, DOI: https://doi.org/10.21776/ub.mps.2021.007.01.5

Received: 21-10-2020. Revised: 12-02-2021. Accepted: 22-03-2021. Published online: 24-06-2021

Handling Editor: Intan Rahmawati, Universitas Brawijaya, Indonesia

*Corresponding author: Sunarno, Fakultas Ushuluddin dan Dakwah, Institut Agama Islam Negeri (IAIN)

Kediri, Kediri, Indonesia. E-mail: sunarno@iainkediri.ac.id

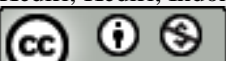

This work is licensed under a Creative Commons Attribution-NonCommercial 4.0 International License.

How to cite this article in accordance with the American Psychological Association (APA) $7^{\text {th }}$ guidelines: Sunarno \& Sulistyowati, E. (2021). Resiliensi komunitas di tengah pandemi Covid-19. MEDIAPSI, 7(1), $37-$ 52. https://doi.org/10.21776/ub.mps.2021.007.01.5 


\section{Pendahuluan}

Pada 21 April 2020, Food and Agriculture Organization of the United Nations (FAO), International Fund for Agriculture Development (IFAD), dan World Bank and World Food Programme (WFP) di Pertemuan Luar Biasa Menteri Pertanian Dunia G20 memberikan pernyataan tentang dampak Covid-19 pada ketahanan pangan dan gizi. Bahwa pandemi Covid-19 telah menyebabkan hilangnya kehidupan manusia secara dramatis, bagi dunia-baik sosial, ekonomi, termasuk ketahanan pangan dan gizi (Mardones dkk., 2020). Gambar 1 di bawah ini ditampilkan untuk mengetahui seberapa dramatis Covid-19 telah menjadi sebab hilangnya kehidupan manusia tersebut, dapat dipahami dari data FAO berikut ini:

\section{Gambar 1. FAO Datalab.}

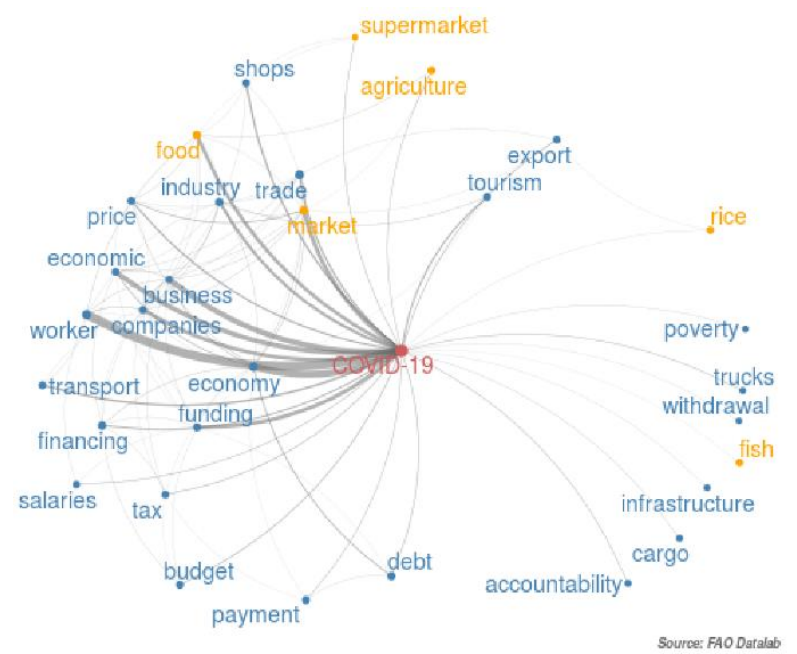

Data tersebut menunjukkan betapa dampak Covid-19 akan mengalami jaringjejaring - sebuah jaringan dampak yang kompleks. Covid-19, selain mengancam kesehatan kepada yang rentan penyakit juga mengancam ketahanan pangan yaitu krisis kelaparan. Banyak negara yang me-lockdown ekonomi demi memperlambat laju sebaran virus Corona. Pandemi yang berlarut menyebabkan pasokan makanan, petani, hasil pertanian, pengolahan pertanian, pengiriman, pengecer, dan masih banyak lagi, terganggu. Inilah satu kondisi yang oleh The Food and Agriculture Organization (FAO) disebut sebagai 'krisis dalam krisis' (The Food and Agriculture Organization, 2020). FAO memberikan himbauan untuk bertindak secara kolektif dalam mengatasi ancaman ketahanan pangan dan gizi yang disebabkan pandemi Covid-19.

Menanggapi pernyataan sekaligus ancaman ketahanan pangan dan gizi yang disampaikan oleh FAO tersebut, Presiden RI Joko Widodo memerintahkan jajarannya untuk terus mengontrol ketersediaan bahan pangan. Kementerian Pertanian satu diantaranya untuk menjamin ketersediaan bahan pangan sampai ke daerah-daerah dengan memberikan bantuan subsidi pengangkutan dari daerah surplus ke daerah minus ("Kementan siapkan strategi ketahanan pangan di tengah pandemic covid-19", 2020). Pangan menjadi sektor penting di masa pandemi Covid-19.

Selain risiko dampak penyakit Covid-19 dan ancaman ketahanan pangan, pandemi coronavirus juga mengancam keamanan dan ketertiban. Menurut Direktur Reskrimum Polda Metro Jaya Kombes Pol Suyudi Ario Seto (Wibowo, 2020) ancaman keamanan dan ketertiban dapat dipicu oleh lesunya perekonomian yang menyebabkan bertambahnya orang miskin baru. Senada dengan Suyudi, Koordinator Bidang Perencaan Gugus Tugas Wisnu Widjaja menyatakan bahwa pandemi Covid-19 meningkatkan kelompok miskin baru yang bisa mendorong perilaku kejahatan. Di Jakarta, rentang 6 hingga 19 April 2020 kasus kejahatan pencurian dan pencurian bermotor meningkat 12 persen (Triyasni, 2020). 
Sementara di Serang, sepanjang tahun 2020 kasus kejahatan meningkat 8 persen (Ridho, 2020).

Meningkatnya kasus kejahatan tersebut, sesuai dengan hasil penelitian yang dilakukan oleh Triana \& Fauzi (2020) terhadap peningkatan kriminalitas di Surabaya di masa pandemi Covid-19. Bahwa pandemi mengakibatkan perubahan perilaku pada seseorang yang bersifat menyimpang salah satunya adanya aksi pencurian yang dilatarbelakangi oleh faktor sosial dan ekonomi. Salah satu sebab munculnya perubahan perilaku tersebut adalah kehilangan pekerjaan.

Ketiga ancaman berupa penyakit, ancaman ketahanan ekonomi, dan ancaman keamanan dirasakan oleh para warga Dusun Tempurejo. Sebagaimana data yang didapatkan oleh peneliti pada saat di lapangan. Terkait ancaman penyakit, warga mengungkapkan: "Nek wayah pagebluk ngene kan awake dhewe kudhu waspada. Kabehkabeh isok terpapar, dadine padha-padha njaga wae, jaga jarak, tapi ya aja kenemenen sampek emoh bersosial (Di waktu pandemi seperti ini kita semua harus waspada. Siapapun bisa terpapar, jadi harus sama-sama menjaga, jaga jarak, tapi juga jangan keterlaluan sampai tidak bersosial) (W1.S1.KK: 115-117).

Ancaman terhadap ketahanan ekonomi sebagaimana diungkapkan warga, "Setelah adanya penutupan Alaska, warga yang awalnya menggantungkan hidup dari berdagang di sana mengalami penurunan pendapatan yang sangat drastis. Yang biasanya pendapatan ada di kisaran ratusan ribu bahkan juta. Sekarang sama sekali tidak ada pemasukan. Bahkan, beberapa warga di awal-awal penutupan wisata banyak yang mengeluh mau kerja apa, mau makan apa"
(W1.S3.SS: 202-206); sedangkan ancaman terhadap keamanan dapat dipahami dari salah satu ungkapan warga lain, "Rodok was-was $a k u$, Mbak. Opo meneh saiki sing jenenge jambret, maling tansoyo akeh. Gek sadissadis pisan" (Agak was-was saya, Mbak. Apalagi sekarang jambret dan maling semakin banyak. Dan mereka juga sadis) (W1.S2.RR: 230-231).

Dusun Tempurejo adalah salah satu dusun yang wilayahnya masih tergolong asri dan alami. Di sini masih terbentang pemandangan area persawahan juga hutan. Masyarakat sebagian besar menggantungkan hidupnya pada alam. Awalnya, mereka sebagian besar bertani tetapi setelah dibukanya Wisata Alam Alaska, sebagian beralih menjadi pedagang di kawasan wisata. Adanya Covid-19, berimbas pada penutupan kawasan Wisata Alam Alaska. Hal ini mengakibatkan warga tidak bisa berdagang lagi di kawasan wisata selama beberapa waktu. Akhirnya, warga yang berdagang di Alaska mulai untuk kembali bekerja di sawah/tegal serta membuka warung di rumah untuk mempertahankan kehidupannya.

Masyarakat Dusun Tempurejo masuk kategori masyarakat tradisional, yaitu sebuah masyarakat yang masih memegang nilai, sikap, dan norma yang selama ini secara turun temurun terwariskan dari para pendahulunya. Sebuah set kepercayaan dan praktik-praktik hidup yang menjadi identitas khusus satu kelompok sosial dan pembeda dengan yang lain inilah yang disebut budaya (Hogg dkk., 2017). Hofstede (2011) menjelaskan bahwa budaya sebagai pemrograman kolektif pikiran yang membedakan anggota satu kelompok atau kategori orang dari yang lain. Budaya memengaruhi apa yang dipikirkan, bagaimana merasakan, bagaimana berpakaian, apa dan bagaimana makan, bagaimana berbicara, 
nilai-nilai dan prinsip-prinsip moral apa yang dipegang, bagaimana berinteraksi satu sama lain dan bagaimana memahami dunia di sekitar. Budaya menanamkan perilaku dan merupakan sumber kehidupan kelompok etnis dan nasional.

Komunitas, sebagaimana yang didefinisikan oleh The International Federation of Red Cross and Red Crescent Societies (IFRC; 2014) adalah sebagai sekelompok orang yang mungkin tinggal di daerah yang sama, desa atau lingkungan, berbagi budaya yang sama, kebiasaan dan sumber daya. Komunitas adalah sekelompok orang yang memiliki ancaman dan risiko yang sama seperti penyakit, politik, masalah ekonomi, dan bencana alam. Suatu komunitas dapat diartikan sebagai 'masyarakat setempat', dimana kelompok tersebut dapat memenuhi kebutuhan hidup memiliki perasaan sebagai anggota kelompok dan terjadi interaksi antar anggotanya (Yuriadi, 2018).

$$
\text { Hillery (1955) menggambarkan }
$$
komunitas sebagai organisasi sosial, baik formal maupun informal yang dibatasi oleh lokasi geografis atau dibentuk atas dasar kepentingan dan tujuan bersama, juga kebutuhan (terhadap hobi, kelompok politik), dan jaringan kerabat. Dalam kehidupan sosial masyarakat, psikologi komunitas memiliki pandangan dalam memahami perilaku manusia berdasarkan kepada kontekstual. Kata 'konteks' dalam pernyataan tersebut digunakan dalam arti luas. Ditilik dari subyek, psikologi komunitas memiliki kebutuhan untuk melihat orang - perasaan, pikiran, dan tindakan-dalam konteks sosial tertentu. Konteks yang dipikirkan tidak berhenti pada lingkungan sosial, keluarga atau persahabatan atau kelompok kerja (sitem level mikro), tetapi diperluas ke konteks level menengah dan makro. Sehingga psikologi komunitas mampu melihat dengan jernih kesehatan, kebahagiaan, dan kesejahteraan manusia, bahkan tentang kesusahan dan kekacauan seseorang dari konteks (Orford, 2008).

Selain memliki ide sentral menghargai konteks dalam memahami perilaku orang, psikologi komunitas memiliki tujuan tidak hanya untuk menganalisis kekuatan dan cara, tetapi untuk menemukan cara bagaimana membantu manusia dalam memerangi ketidaksetaraan dan ketidakadilan, dan untuk bekerjasama dengan orang-orang untuk melawan penindasan dan berjuang menciptakan dunia yang lebih baik. Rappaport (1981), menegaskan bahwa analisis masalah dari konteks akan menyebabkan pemahaman yang berbeda tentang masalah, maka intervensinya pun akan lebih efektif.

Nilai-nilai inti dari psikologi komunitas adalah pemberdayaan (empowerment), pembebasan (liberation), dan keadilan sosial (social justice) (Orford, 2008). Pemberdayaan adalah nilai-orientasi sentral dari psikologi komunitas, dimana orang, organisasi, dan masyarakat mendapatkan penguasaan atas masalah yang menjadi perhatian mereka. Untuk mengembangkan psikologi pembebasan diperlukan praksis baru yang memerlukan dua hal, yaitu refleksi, pemahaman, kesadaran kritis. Kedua adalah tindakan untuk mengubah keadaan dari proses refleksi kritis (Orford, 2008). Nilai keadilan sosial, sementara itu, mencerminkan promosi perdamaian dan menentang kekerasan dalam segala bentuknya (Orford, 2008).

Salah satu upaya pemberdayaan komunitas dalam hal mengatasi bencana adalah mengembangkan resiliensi komunitas. IFRC (2014) mendefinisikan resiliensi sebagai kemampuan individu, komunitas, 
organisasi atau negara yang terpapar bencana, krisis, dan kerentanan mendasar untuk mengantisipasi dan mempersiapkan mengurangi dampak, serta mengatasi dan memulihkan efek guncangan dan tekanan tanpa mengkompromikan prospek jangka panjang. Berdasarkan definisi tersebut, resiliensi dapat diamati dan diperkuat di beberapa level, yaitu level individu, level rumah tangga, level komunitas, pemerintah lokal, pemerintah nasional, organisasi perhimpunan nasional, dan level regional dan global. Pada level komunitas, resiliensi komunitas diperkuat oleh level ketahanan individu dan rumah tangga.

Resiliensi komunitas menurut van Breda (2001) adalah kemampuan memanfaatkan sumber daya yang dimiliki oleh suatu komunitas untuk kembali bangkit dari situasi menekan, trauma, atau kejadian yang membuat guncangan sehingga komunitas tersebut dapat tumbuh dan berkembang secara berkelanjutan. Menurut Kirmayer dkk. (2012; lihat juga Yuriadi, 2018), resiliensi komunitas merupakan gagasan tentang bagaimana masyarakat bertahan menghadapi tekanan dan tantangan hidup melalui fungsi relasi sosial. Beberapa aspek resiliensi komunitas dapat dilihat (Cinderby dkk., 2016; Windle dkk., 2011) melalui, pengetahuan komunitas seputar ancaman bencana, keterlibatan komunitas dalam respon bencana, adanya jaringan sosial untuk merespon dan pemulihan bencana, terjadinya perubahan positif dan mampu bangkit setelah bencana, dan memiliki kepercayaan kepada pemerintah dan tokoh masyarakat.

Bruneau dkk. (2003) mendefinisikan resiliensi komunitas sebagai kemampuan unit sosial (misalnya organisasi, masyarakat) untuk memitigasi bencana dan melakukan kegiatan-kegiatan pemulihan dengan cara meminimalkan gangguan sosial. Tujuannya adalah untuk meminimalkan hilangnya nyawa dan kerugian ekonomi. Singkatnya, untuk meminimalisasi kurangnya kualitas hidup akibat bencana. Sementara, dalam konteks keamanan kesehatan nasional (national health security), resiliensi komunitas sangat penting untuk membatasi kebutuhan bantuan di saat bencana berkepanjangan. Untuk meningkatkan resiliensi, Chandra dkk. (2013) menekankan bahwa masyarakat harus membangun kemampuan yang ditandai dengan ketahanan menahan stres, ketahanan keragaman, dan ketahanan kecepatan mobilisasi sumber daya.

Dampak bencana bervariasi di antara berbagai komunitas. Beberapa komunitas memiliki ketangguhan dalam menghadapi bencana, sementara bagi beberapa komunitas yang lain tidak. Memahami kapasitas dan karakteristik masing-masing komunitas akan memberikan kontribusi terhadap upaya pencegahan dan rehabilitasi bencana dengan lebih baik. Oleh karena itu, sesuai dengan pendapat Drabek dkk. (2018; lihat juga Jovita dkk., 2019) yakni menjadi penting untuk mempertimbangkan struktur sosial komunitas. IFRC (2014) memberikan beberapa karakteristik komunitas yang tangguh adalah yang berpengetahuan luas, sehat dan dapat memenuhi kebutuhan dasarnya, adanya kohesi sosial, memiliki peluang ekonomi, memiliki infrastruktur dan layanan yang terpelihara dengan baik dan mudah diakses, dapat mengelola aset alamnya, dan saling terhubung.

Beberapa penelitian terkait resiliensi komunitas banyak dilakukan dengan menyertakan variabel modal sosial dalam mengatasi kebencanaan. Seperti penelitian yang dilakukan oleh LaLone (2012), 
berpendapat bahwa resiliensi komunitas terhadap bencana lingkungan perlu jaringan modal sosial informal di tingkat lokal, serta perlu kebijakan dan perencanaan yang lebih formal. Hal ini dibuktikan di Appalacia (Amerika Serikat Timur) yang dihantam tornado pada April 2011 dengan mobilisasi sumber daya dan tenaga kerja serta pasokan dengan cepat dihasilkan melalui jejaring sosial masyarakat lokal di minggu-minggu pertama respon pemulihan bencana. Penelitian lain yang dilakukan oleh Jovita dkk. (2019) yang meneliti modal sosial membentuk pascabencana dampak Topan 2011 di Filipina, mengungkapkan bahwa solidaritas di antara masyarakat berkontribusi pada pemulihan para korban dimana solidaritas tersebut adalah bagian dari struktur normatif masyarakat.

Sementara, penelitian-penelitian terkait resiliensi komunitas di Indonesia diantaranya dilakukan oleh Rezeky dkk. (2018), yang meneliti sistem nilai dan resiliensi komunitas dalam pengelolaan Rawa Lebak di Desa Tapus, Kecamatan Pampangan, Kabupaten Ogan Komering Ilir. Hasil penelitian ini didapati nilai sosial berupa ritual sebelum musim tanam padi, nilai ekonomi didapatkan dari Rawa Lebak sebagai sumber mata pencaharian utama bagi masyarakat, sedangkan nilai politik dilihat dari penguasaan lahan Rawa Lebak. Novianty (2011), mengadakan penelitian kepada warga pascagempa di Klaten dengan pendekatan kuantitatif menggunakan metode survei yang bertujuan untuk mengetahui korelasi antara ketahanan masyarakat dan komunitas jangka panjang dalam mengatasi gempa. Adapun hasilnya adalah ada korelasi positif antara ketangguhan masyarakat dan penanggulangan pascagempa yaitu $r=.57, p<.001$. Juga penelitian yang dilakukan Ali dkk. (2019), yang meneliti dengan judul Community Resilience in Dealing with Tempe Lake Disaster di Sulawesi Selatan, dengan pendekatan kualitatif. Hasil penelitian menunjukkan bahwa masyarakat mengadakan ritual Maccera Tappareng ketika air meluap menyebabkan banjir sebagai permintaan kepada penguasa danau. Rumah terikat dengan baik sehingga tidak hanyut. Namun, di saat banjir masyarakat mendapatkan berkah tangkapan ikan.

Dari uraian tersebut, maka peneliti tertarik menggali resiliensi komunitas di Dusun Tempurejo, Desa Tempurejo, Kecamatan Wates, Kabupaten Kediri dalam mengatasi pandemi Covid-19. Maka, selain penelitian ini belum pernah dilakukan oleh peneliti sebelumnya, penelitian ini juga memiliki kebaruan, yaitu ada pada tujuan penelitian untuk mengidentifikasi nilai dan perilaku sosial dalam konteks resiliensi komunitas di tengah pandemi Covid-19.

\section{Metode}

\section{Partisipan dan desain penelitian}

Penelitian ini dilakukan di Dusun Tempurejo, Desa Tempurejo, Kecamatan Wates, Kabupaten Kediri. Jumlah partisipan dalam penelitian ini adalah lima orang yaitu seorang perangkat desa dan empat orang warga asli Dusun Tempurejo. Dimana partisipan adalah orang-orang yang terlibat secara lansung dalam kegiatan-kegiatan yang ada di Dusun Tempurejo.

Untuk memahami secara komprehensif dan mendalam seputar resiliensi komunitas di tengah pandemi Covid-19 di Dusun Tempurejo, Desa Tempurejo, Kecamatan Wates, Kabupaten Kediri, maka peneliti menggunakan metode kualitatif dengan pendekatan studi kasus. Pendekatan ini dipilih karena penelitian ini terfokus pada sebuah 
kasus yaitu pandemi Covid-19 yang kemudian akan diamati dan dianalisis secara cermat hingga tuntas. Fokus kajiannya adalah resiliensi komunitas di tengah pandemi Covid-19 di Dusun Tempurejo, Desa Tempurejo, Kecamatan Wates, Kabupaten Kediri. Resiliensi komunitas adalah ketangguhan masyarakat untuk berdaya dan bangkit dari tekanan, trauma, dan guncangan dalam menghadapi bencana. Dengan beberapa aspek: pertama, pengetahuan komunitas seputar ancaman bencana; kedua, keterlibatan komunitas dalam respon bencana; ketiga, adanya jaringan sosial untuk merespon dan pemulihan bencana; keempat, terjadinya perubahan positif dan mampu bangkit setelah bencana; dan kelima, memiliki kepercayaan kepada pemerintah dan tokoh masyarakat.

\section{Prosedur dan pengukuran}

Pengumpulan data dilakukan dengan wawancara dan observasi. Kemudian data yang terkumpul dianalisis dengan menggunakan analisis tema, yaitu melakukan proses pengodean ke dalam tema-tema atau kategori yang ada (Creswell \& Poth, 2016). Dalam konteks penelitian ini proses pengodean dengan pengklasifikasian perilakuperilaku yang muncul ke dalam tema-tema yang ada dalam psikologi sosial. Dilanjutkan dengan menganalisis hasil pengklasifikasian untuk melihat faktor psikologis apa yang mampu membangun resiliensi komunitas dalam menghadapi Covid-19.

\section{Hasil}

Dari hasil wawancara dan observasi, peneliti menemukan faktor psikologis yang mampu membangun resiliensi komunitas dan beberapa nilai serta perilaku sosial untuk menghadapi bencana pandemi Covid-19 di Dusun Tempurejo. Faktor-faktor tersebut yaitu sense of belonging, identifikasi nilai, dan identifikasi perilaku sosial.

Sense of belonging, rasa memiliki terhadap sesama warga adalah faktor psikologis yang dimiliki warga sehingga mampu membangun resiliensi komunitas. Rasa memiliki terhadap sesama warga tersebut terungkap dengan satu pernyataan, bahwa para warga merasa sebagai satu warga dusun karena sudah lama hidup bersama: "Awake dhewe wis urip bareng ket jaman mbah-mbahe mbiyen" (Kita semua sudah lama hidup bersama sejak jaman simbahsimbah pendahulu) (W1.S1.KK: 157; W1.S2.RR: 105; dan W1.S4.NN: 88). Rasa tersebut menjadi dasar antarwarga saling merasakan apa yang dirasakan oleh warga lainnya. "Ora tego yen ngerti ana tanggane kasusahan, terus mek meneng wae. Selagi enek, mbantu sithik-sithik. Urip barengbareng, yen ana susah senenge kudhu padha mbantu" (Tidak tega apabila mengetahui ada tetangga yang kesusahan, tetapi hanya diam. Selagi memiliki, ya membantu meskipun sedikit. Hidup secara bersama-sama, kalau ada susah dan senang ya harus saling membantu) (W1.S1.KK: 277-278; W1.S2.RR: 358-260; dan W1.S4.NN: 175-177).

Faktor selanjutnya adalah Identifikasi Nilai. Ada beberapa nilai yang dimiliki oleh warga Dusun Tempurejo. Pertama, adalah gotong royong. Semenjak adanya pandemi Covid-19, budaya gotong royong di Dusun Tempurejo semakin menguat. Semakin menguatnya budaya gotong royong di Dusun Tempurejo dibuktikan dengan ikut sertanya warga dalam kegiatan penyemprotan disinfektan di lingkungan RT masing-masing dan ikut sertanya warga dalam menjaga keamanan lingkungan melalui kegiatan siskamling. Warga secara bersama-sama mendukung dan melaksanakan kegiatan ini 
dengan harapan agar pandemi Covid-19 bisa segera berakhir.

Penyemprotan disinfektan di masingmasing RT dilakukan oleh warga sendiri yang dikoordinasi oleh Ketua RT masing-masing. Penyemprotan dilakukan setiap hari Minggu, dimana setiap minggunya warga secara bergantian melakukan penyemprotan. Kegiatan penyemprotan disinfektan disambut baik oleh warga. Penyemprotan di lingkungan warga Dusun Tempurejo dilaksanakan rutin setiap minggu. Jadi, setiap Minggu warga bergantian jadwal menyemprot, dengan tujuan untuk menjaga lingkungan secara bersamasama sehingga para warga tetap sehat dan dijauhkan dari virus Corona (W1.S1.KK: 308311; W1.S4.NN: 413-416; W1.S5.GG: 273274).

Gotong royong tersebut didasari oleh kesadaran bersama bahwa pencegahan virus Corona tidak bisa dilakukan sendiri-sendiri. Pemerintahan desa dengan para aparat tidak bisa berjalan sendiri, tetap membutuhkan kerja sama bersama warga. Dan karena para warga menyadari pentingnya kerja gotong royong dalam hal mencegah virus Corona, para warga menyambut atas keterlibatan dalam penyemprotan disinfektan yang dilakukan setiap hari Minggu serentak di semua RT (W1.S3.SS: 379-386; dan W1.S4.NN: 492-494).

Selain penyemprotan disinfektan, gotong royong juga dilakukan dalam bentuk siskamling yang dilaksanakan setiap hari oleh warga. Sebelumnya, kegiatan siskamling tidak ada di dusun ini, tetapi setelah adanya pandemi yang menyebabkan meningkatnya kriminalitas di daerah-daerah lain, membuat warga berinisiatif untuk mengadakan siskamling. Siskamling adalah kegiatan yang diinisiasi oleh warga sendiri yang dikomunikasikan pada pihak desa dan akhirnya terealisasikan. Setiap harinya, di Dusun Tempurejo diadakan siskamling. Warga pun secara aktif terlibat dalam kegiatan ini (W2.S1.KK: 63-66; W2.S3.SS: 401-406; dan W2.S5.GG: 106-110).

Siskamling tersebut dilaksanakan setiap malam di setiap harinya demi menjaga keamanan Dusun Tempurejo. Sebab, di desadesa tetangga sudah terjadi pencurian (W2. S2.RR: 402-403; W2.S3.SS: 467; W1.S1.KK: 444-445; dan W2.S5.GG: 303-304). Selain menjaga keamanan dusun, siskamling juga menjadikan kedekatan persaudaraan antarwarga, "Mbendino warga ronda. Ronda iki kan ya tambah iso ngraketne paseduluran" (W2.S2.RR: 404-405).

Kedua, adalah musyawarah. Setiap pengambilan keputusan, pemerintah desa dengan warga Tempurejo mempraktikkan musyawarah yang dilandasi oleh kebijaksanaan para warga. Pemerintah desa mengkomunikasikan kebijakan-kebijakan yang diambil dengan warga melalui ketua RT masing-masing. Begitupun sebaliknya, warga juga diberi kesempatan untuk mengkomunikasikan segala kritik atau usulan. Jadi, antara pemerintah desa dengan warga tidak sampai ada kesalahpahaman akibat miskomunikasi (W1.S1.SS: 692-693; dan W2.S5.GG: 284).

Musyawarah adalah hal yang diterapkan antara pemerintah desa dengan warga. Dimana RT sebagai jembatan penghubung penyampai aspirasi warga sekaligus penyampai kebijakan desa. Di situasi pandemi Covid-19, musyawarah tidak hanya dilakukan secara langsung (pertemuan), tetapi beberapa kali juga diadakan melalui grup WhatsApp RT (W1.S5.GG: 316). Penggunaan media komunikasi untuk musyawarah merupakan hal yang tepat, dikarenakan diskusi bisa dilakukan sewaktu-waktu dan informasi 
apapun bisa secara cepat tersampaikan kepada warga (W1.S3.SS: 697-699; W1.S3.SS: 703705; dan W1.S5.GG: 318).

Ketiga, keselarasan dengan alam. Dusun Tempurejo sebagian wilayahnya berupa area persawahan dan hutan. Hal ini berdampak pada mata pencaharian penduduk sekitar, mayoritas penduduk menggantungkan hidupnya pada alam. Warga ada yang bertani dan ada yang berdagang di kawasan Wisata Alam Alaska. Akan tetapi, setelah adanya penutupan wisata saat pandemi Covid-19, banyak warga yang kehilangan pekerjaannya karena tidak bisa berjualan di Alaska. Pada dua minggu pertama setelah penutupan Wisata Alam Alaska, banyak warga terdampak yang mengeluhkan penutupan kawasan wisata. Sebab, beberapa warga yang biasanya memiliki pendapatan ratusan ribu bahkan juta rupiah, di saat pandemi Covid-19 para warga tidak memiliki pendapatan. Maka, para warga tidak punya pilihan selain kembali ke alam (W1.S3.SS: 112-116). Para warga mulai bangkit, kembali bekerja di sawah, tegal, dan menjadi buruh tani (W1.S1.KK: 139-141; W1.S3.SS: 189-194; dan W1.S2.RR: 328-333).

Alam juga dijadikan warga sebagai tempat melepas kejenuhan saat menghadapi pandemi Covid-19. Sebelum pandemi, anakanak usia sekolah sangat jarang meluangkan waktunya di alam. Mayoritas anak sudah disibukkan dengan kegiatan-kegiatan sekolah sejak pagi hingga sore, belum lagi mengikuti les tambahan. Akan tetapi, sejak adanya pandemi, anak-anak semakin dekat dengan alam, mereka meluangkan waktunya untuk berolahraga di hutan dan sungai yang ada di Dusun Tempurejo. Anak-anak melepas kejenuhan dengan kembali menyatu dengan alam (W1.S1.KK: 512-515; dan W1.S3.SS: 299-303).
Selain 'sense of belonging' dan 'identifikasi nilai', faktor selanjutnya yaitu Identifikasi Perilaku Sosial. Ada beberapa perilaku sosial yang ditunjukkan oleh warga Dusun Tempurejo. Pertama, kepatuhan (obedience) terhadap pemerintah desa. Selama pandemi Covid-19 ada beberapa kebijakan yang diterapkan oleh pihak desa. Dimana kebijakan-kebijakan ini bertujuan untuk memutus mata rantai penyebaran Coronavirus. Salah satu kebijakan yang diambil pemerintah desa adalah melakukan penutupan Wisata Alam Alaska. Ini adalah salah satu keputusan besar yang diambil pemerintah desa dikarenakan warga akan terdampak secara langsung dari segi ekonomi. Dimana mayoriras warga menggantungkan hidupnya dari aktivitas perdagangan di kawasan wisata. Warga menerima dan mendukung keputusan tersebut meskipun di awal ada rasa berat hati (W1.S3.SS: 529-533; dan W1.S5.GG: 441-443).

Penutupan Wisata Alam Alaska pada awalnya kurang bisa diterima oleh warga. Akan tetapi, setelah paham akan bahayanya virus ini, warga mulai menerima dan patuh akan kebijakan yang diambil oleh pemerintah. Saat ini warga sudah mulai bangkit lagi dengan mencari pekerjaan lain, ada yang membuka warung di rumah dan kembali bekerja di sawah dan tegal (W1.S3.SS: 199204; dan W1.S3.SS: 535-537).

Kebijakan lain yang diambil oleh pemerintah desa adalah penutupan sebagian akses jalan untuk mengurangi mobilisasi warga. Warga mematuhi keputusan ini dengan ikut membantu secara langsung saat proses penutupan sebagian akses jalan. Selain itu, pemerintah desa juga menghimbau warga untuk melaksanakan protokol kesehatan seperti yang dianjurkan oleh pemerintah. Diantaranya memakai masker, mencuci 
tangan, dan mengurangi kerumunan. Sebagian warga sudah mulai mematuhi himbauan tersebut dengan selalu memakai masker saat bepergian, mencuci tangan, dan tidak mengadakan kegiatan-kegiatan yang melibatkan banyak orang seperti pengajian, tahlilan, dan resepsi pernikahan.

Kedua, neighborhood yang sehat. Warga Dusun Tempurejo sadar akan perlunya menjaga kondisi lingkungan bertetangga yang sehat selama pandemi Covid-19. Hal ini ditunjukkan dengan sikap warga terhadap warga lain yang sedang melakukan karantina mandiri. Warga memberikan dukungan dan semangat pada warga yang melakukan karantina mandiri. Tidak ada tindakan yang bersifat mengucilkan, menghakimi, atau menyalahkan warga yang pulang dari perantauan (W1.S4.NN: 119-122). Warga juga mengingatkan warga lain yang pulang dari perantauan untuk segera melaporkan diri ke pihak desa dan segera melakukan karantina mandiri. Saat ada warga yang menyalahi aturan (dalam artian tidak melakukan karantina mandiri selama 14 hari), mereka akan menegur dengan 'nada candaan' agar pihak yang ditegur tidak tersinggung (W1.S4.NN: 119-122; W2.S5.GG: 67-68; dan W2.S2.RR: 105-106). Selain itu, warga dan pihak desa juga berusaha untuk selalu mengingatkan dengan baik. (W2.S3.SS: 368371).

Ketiga, adalah prososial. Bentuk perilaku prososial atau saling tolong menolong diwujudkan tidak hanya berupa barang, melainkan juga dengan saling mendukung, menguatkan, dan memberi motivasi pada warga yang mulai mengeluhkan keadaan. Perilaku prososial antarwarga didasari oleh perasaan sama-sama susah di masa pandemi (W1.S2.RR:455-460; dan W1.S3.SS: 423-427).
Wujud lain dari perilaku prososial adalah di antara para warga juga membantu secara tidak langsung dengan sering membeli kebutuhan pokok di warung-warung kecil yang ada di sekitar rumah. Adanya perilaku membeli kebutuhan pokok di warung milik warga setempat, secara otomatis warga ikut membantu keberlangsungan hidup warga lain (W1.S1.KK: 453-459; dan W1.S4.NN: 501504). Di sini terlihat kepedulian dan kerja sama sudah terjalin begitu baik antar warga. Tanpa adanya aba-aba dari siapapun, warga sudah memiliki kesadaran untuk membantu sesama yang didasari atas rasa memiliki antar warga.

\section{Diskusi}

Sense of belonging atau rasa memiliki sesama warga menjadi faktor psikologis bagi terwujudnya resiliensi komunitas di Dusun Tempurejo. Menguatnya rasa memiliki sebagai sesama warga Dusun Tempurejo menjadikan para warga memegang dan mempraktikkan warisan nilai-nilai budaya yang melahirkan perilaku-perilaku sosial antarwarga. Dimana nilai-nilai dan perilaku sosial warga secara fungsional mampu dijadikan sebagai modal sosial menghadapi bencana pandemi Covid-19.

Dalam konteks kelompok, sense of belonging dapat dikaji melalui sense of community (kesadaran komunitas). Sebagaimana di hasil penelitian bahwa para warga merasa saling memiliki dimana mereka sudah sejak lama hidup bersama di Dusun Tempurejo, sehingga antarwarga merasa satu kelompok yaitu satu Dusun Tempurejo, dan merasa memiliki antarsesama warga-inilah kesadaran komunitas. Para warga Dusun Tempurejo tidak hanya melakukan interaksi fisik, tetapi juga interaksi emosi dan tindakan dalam bertahan di masa pandemi Covid-19. 
Kesadaran para warga terhadap antarwarga sebagai sesama warga dusun tersebut sesuai dengan pernyataan Theodori dan Kyle (2013; lihat juga Mannino \& Snyder, 2012) terkait dengan sense of community, bahwa kesadaran komunitas tidak hanya keterikatan geografis dalam hal ini tempat atau wilayah tertentu, tetapi juga interaksi emosi, keyakinan, dan tindakan.

Kesadaran komunitas oleh McMilan dan Chavis (1986) didefinisikan sebagai perasaan memiliki dan juga sebagai sebuah perasaan bahwa para anggota di dalam satu kelompok memiliki arti penting bagi satu anggota terhadap anggota lainnya, serta memiliki keyakinan bahwa kebutuhan para anggota akan terpenuhi oleh antaranggota melalui komitmen bersama sebagai satu kelompok. Hal ini terjadi di Dusun Tempurejo, dimana antarwarga saling menolong dalam mencukupi kebutuhan dengan memberikan sembako dan membeli kebutuhan di warung warga setempat.

Dalam psikologi, kesadaran komunitas dianggap sebagai penyangga terhadap tantangan berat yang dihadapi oleh seseorang. Komunitas menawarkan dukungan yang berasal dari orang-orang terdekat dengan model interaksi sosial yang berkelanjutan dan bermakna. Bahkan, gagasan kesadaran komunitas melampaui dukungan sosial yang juga berfokus kepada hal positif dalam aspek komunitas. Bagi psikolog, profesional, dan pemangku kebijakan ada kebutuhan nyata untuk mengembangkan kesadaran komunitas dalam suatu komunitas sehingga dapat memberikan pelayanan dan intervensi dengan dampak positif kepada kesehatan fisik dan mental (Michalski dkk., 2020; Terry dkk., 2019).

Riger \& Lavrakas (dalam McMilan \& Chavis, 1986) mempelajari kesadaran komunitas sebagaimana tercermin dalam keterikatan lingkungan. Menurut Riger dan Lavrakas (dalam McMilan \& Chavis, 1986), ada dua faktor yang secara empiris meningkatkan keterikatan lingkungan yaitu ikatan sosial dan perilaku yang berdasarkan pada akar. Keterikatan sosial antarwarga Dusun Tempurejo dapat dikatakan begitu kuat, sehingga antartetangga saling memberikan dukungan, saling menolong, dan perilaku para warga didasari atas nilai-nilai yang selama ini terwariskan.

Sementara itu, Nowell dan Boyd (2014) menekankan kesadaran komunitas kepada bagaimana membuat orang merasa bertanggungjawab untuk terlibat dan saling mendukung. Gotong royong yang diwujudkan dengan penyemprotan disinfektan ke rumahrumah warga dan siskamling, juga musyawarah dalam setiap pengambilan keputusan selain merupakan perwujudan dari rasa tanggungjawab, keterlibatan, dan saling mendukung antarwarga dalam mengatasi pandemi Covid-19 juga sarana pemenuhan kebutuhan warga atas perasaan diterima dan dihormati. Hal ini selaras dengan pendapat Baumeister (2011), dengan mengacu pada teori Maslow, bahwa manusia memiliki kebutuhan yang berupa perasaan diterima, dihormati, dan didukung oleh lingkungan. Mengacu pada sikap tersebut, maka hubungan yang sehat akan terjalin.

Lebih jauh, kesadaran komunitas sebagai manifestasi dari rasa memiliki terhadap sesama warga dusun dapat melahirkan satu kondisi kohesi sosial di masyarakat. Kohesivitas atau kekompakan di psikologi menjadi topik jangka panjang terkait dengan kesehatan mental dalam masyarakat. Di psikologi sosial, kohesivitas adalah keterpaduan atas atribut-atribut bersama antar kelompok-kelompok kecil. 
Kohesivitas juga dimaknai sebagai anggota kelompok yang memiliki karakteristik emosi dan perilaku yang sama antara yang satu dengan anggota keseluruhannya. Kohesivitas dalam kesehatan masyarakat dipandang dapat mempengaruhi kesehatan dan sebagai faktor protektif (Bruhn, 2014).

Hogg (2016) mengartikan kohesivitas kelompok sebagai perasaan hangat akan kesatuan dengan sesama anggota. Kohesivitas dengan demikian adalah aspek afektif dari adanya keterpaduan atau kekompakan antaranggota yang dihasilkan oleh daya tarik sosial antaranggota. Daya tarik sosial adalah consensus (kesepakatan) dan cenderung searah, apabila antaranggota terjadi saling sepakat dan searah maka akan menghasilkan perasaan menjadi anggota dari suatu kelompok akan menonjol sebab masingmasing anggota akan mengidentifikasi diri sebagai prototipe kelompoknya.

Pandemi Covid-19 adalah sebuah bencana non alam dimana masih belum diketahui secara pasti kapan pandemi ini akan berakhir. Ketidakpastian yang berkepanjangan ini pasti membawa dampak yang besar pada kehidupan masyarakat baik aspek ekonomi, sosial, budaya, ataupun psikologis. Oleh karena itu, perlu dibangun resiliensi komunitas guna mengajak masyarakat secara luas agar bisa bangkit dari keterpurukan. Masyarakat bisa mengembangkan nilai-nilai dan perilaku-perilaku yang telah mengakar kuat di lingkungannya. Peneliti berharap masyarakat bisa membangun resiliensi komunitas dimulai dari tingkatan terkecil terlebih dahulu yaitu di lingkungan dusun ataupun desa.

Berdasarkan temuan penelitian dan uraian tersebut, peneliti menemukan sebuah roadmap resiliensi komunitas di Dusun Tempurejo, Kecamatan Wates Kabupaten Kediri. Gambar 2 berikut menampilkan roadmap penelitian resiliensi komunitas menghadapi pandemi Covid-19.

Gambar 2. Roadmap Resiliensi Komunitas.

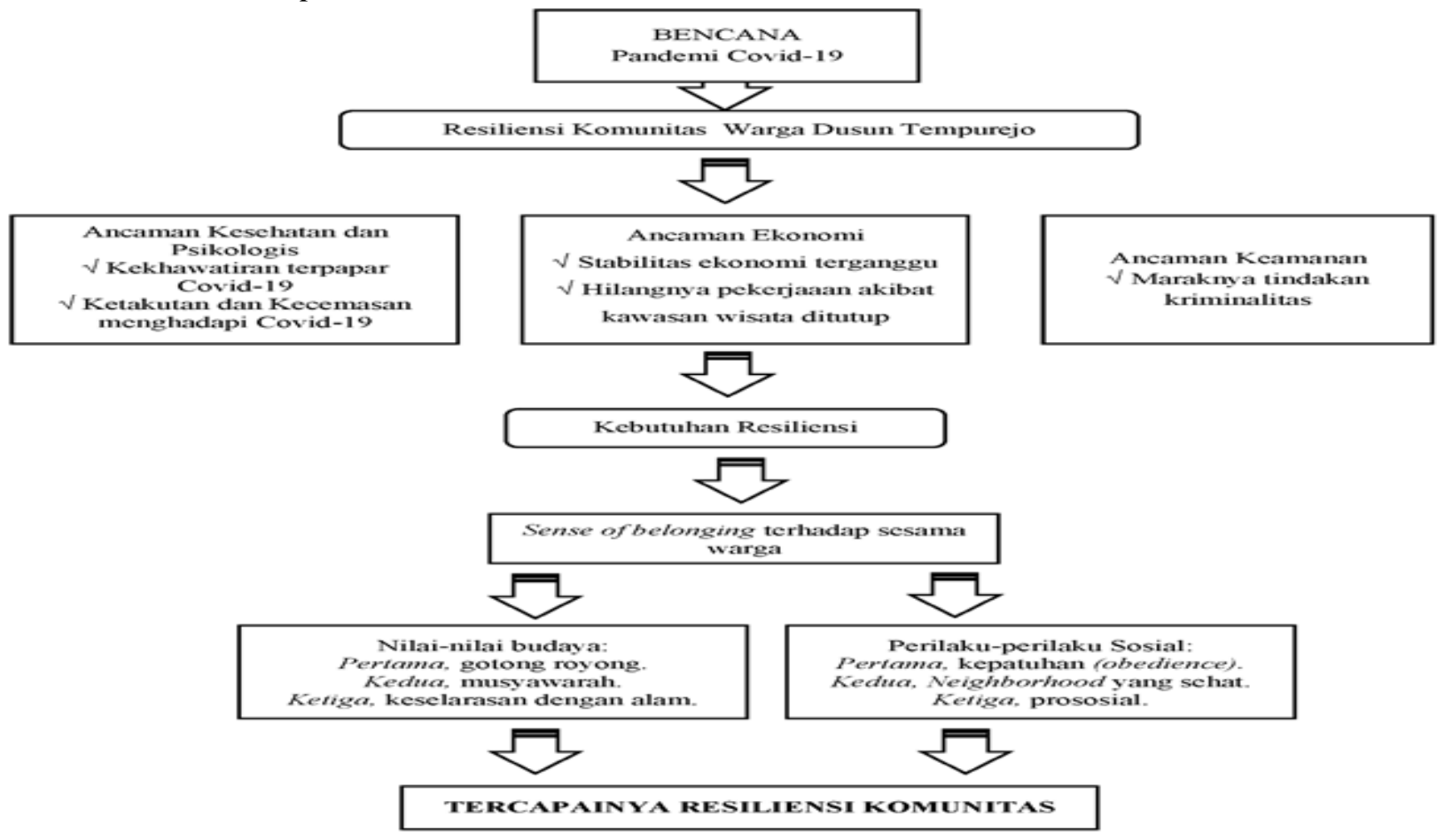




\section{Kesimpulan}

Dari hasil penelitian tersebut dapat disimpulkan bahwa resiliensi komunitas di Dusun Tempurejo lahir dari adanya rasa memiliki (sense of belonging) terhadap kelompok dan para warga yang ada di dalamnya, sehingga nilai-nilai dan perilakuperilaku sosial hidup di dalam masyarakat sebagai kebertahanan di masa pandemi Covid-19. Beberapa nilai yang ada di Dusun Tempurejo terkait resiliensi komunitas adalah nilai gotong royong, musyawarah, dan keselarasan dengan alam. Sedangkan beberapa perilaku sosial selama menghadapi pandemi Covid-19 adalah kepatuhan (obedience), neighborhood yang sehat, dan prososial.

\section{Daftar Pustaka}

Ali, M. S. S., Dahliana, B., Salman, D., Dirpan, A., \& Viantika, I. M. (2019, February). Community resilience in dealing with Tempe lake disaster. IOP conference series: Earth and environmental science (Vol. 235, No. 1, p. 012108). IOP Publishing. https://doi.org/10.1088/17551315/235/1/012108

Baumeister, R. F. (2011). Need-to-belong theory. In P. A. M. Van Lange, A. W. Kruglanski, \& E. T. Higgins (Eds.), Handbook of theories of social psychology (pp. 121-140). Sage Publications.

Bruhn, J. (2014). Group effect. Springer.

Bruneau, M., Chang, S. E., Eguchi, R. T., Lee, G. C., O'Rourke, T. D., Reinhorn, A. M., ... \& Von Winterfeldt, D. (2003). A framework to quantitatively assess and enhance the seismic resilience of communities. Earthquake
Spectra, $\quad$ 19(4), 733-752.

https://doi.org/10.1193/1.1623497

Chandra, A., Williams, M., Plough, A., Stayton, A., Wells, K. B., Horta, M., \& Tang, J. (2013). Getting actionable about community resilience: The Los Angeles county community disaster resilience project. American Journal of Public Health, 103(7), 1181-1189. https://doi.org/10.2105/ajph.2013.3012 70

Cinderby, S., Haq, G., Cambridge, H., \& Lock, K. (2016). Building community resilience: Can everyone enjoy a good life? Local Environment, 21(10), 1252-1270.

https://doi.org/10.1080/13549839.2015 .1100597

Creswell, J. W., \& Poth, C. N. (2016). Qualitative inquiry and research design: Choosing among five approaches. Sage publications.

Drabek, T. E. (2018). Community processes: Coordination. In H. Rodriguez, W. Donner, \& J. E. Trainor (Eds.), Handbook of disaster research (pp. 521-549). Springer.

Hillery, G. (1955). Definition of community: Areas of agreement. Rural Sociology, 20, 111-123.

Hofstede, G. (2011). Dimensionalizing cultures: The Hofstede model in context. Online Readings in Psychology and Culture, 2(1), 23070919.

https://scholarworks.gvsu.edu/cgi/view content.cgi article $=1014 \&$ context $=$ orp $\mathrm{c}$

Hogg, M. A. (2016). Social identity theory. In P. J. Burke (Ed.), Contemporary 
social psychological theories $\left(^{\text {nd }}\right.$ ed.). Stanford University Press.

Hogg, M. A., Abrams, D., \& Brewer, M. B. (2017). Social identity: The role of self in group processes and intergroup relations. Group Processes \& Intergroup Relations, 20(5), 570-581. https://doi.org/10.1177\%2F136843021 7690909

International Federation of Red Cross and Red Crescent Societies. (2014). Framework for community resilience (Research Report No. 1284000 10/2014

https://www.ifrc.org/Global/Document s/Secretariat/Sendai/1284000-

Framework\%20for\%20Community $\% 2$ 0Resilience-EN-LR.pdf

Jovita, H. D., Nashir, H., Mutiarin, D., Moner, Y., \& Nurmandi, A. (2019). Social capital and disasters: How does social capital shape post-disaster conditions in the Philippines?. Journal of Human Behavior in the Social Environment, 29(4), 519-534. https://doi.org/10.1080/10911359.2018 .1556143

Kementan siapkan strategi ketahanan pangan di tengah pandemic covid-19. (2020, 1 Mei).

Tempo.co. https://nasional.tempo.co/read/133774

5/kementan-siapkan-strategi-

ketahanan-pangan-di-tengah-pandemicovid-19

Kirmayer, L. J., Dandeneau, S. D., Marshall, E., Phillips, M. K., \& Williamson, K. J. (2012). Toward an ecology of stories: Indigenous perspectives on resilience. In M. Ungar (Ed.), The social ecology of resilience (pp. 399414). Springer.
Lalone, M. B. (2012). Neighbors helping neighbors: An examination of the social capital mobilization process for community resilience to environmental disasters. Journal of Applied Social Science, 6(2), 209-237. https://doi.org/10.1177/193672441245 8483

Mannino, C. A., \& Snyder, M. (2012). Psychological sense of community: Contributions toward a new understanding. Global Journal of Community Psychology Practice, 3(4), 393-397.

https://www.gjcpp.org/pdfs/2012-

Lisboa-046-

Psychological\%20Sense $\% 20$ of $\% 20 \mathrm{Co}$ mmunity.pdf

Mardones, F. O., Rich, K. M., Boden, L. A., Moreno-Switt, A. I., Caipo, M. L., Zimin-Veselkoff, N., ... \& Baltenweck, I. (2020). The COVID-19 pandemic and global food security. Frontiers in Veterinary Science, 7: 928. https://doi.org/10.3389/fvets.2020.578 508

McMillan, D. W., \& Chavis, D. M. (1986). Sense of community: A definition and theory. American Journal of Community Psychology, 14(1), 6-23. https://doi.org/10.1002/15206629(198601)14:13.0.CO;2-I

Michalski, C. A., Diemert, L. M., Helliwell, J. F., Goel, V., \& Rosella, L. C. (2020). Relationship between sense of community belonging and self-rated health across life stages. SSMPopulation Health, 12: 100676. https://doi.org/10.1016/j.ssmph.2020.1 00676

Naidoo, A.V., Shabalala, N. J., \& Bawa, U. (2003). Community psychology. In L. 
Nicholas (ed.), Introduction to psychology (pp. 423-456). UCT Press.

Novianty, A. (2011). Penyesuaian dusun jangka panjang ditinjau dari resiliensi komunitas pascagempa. Jurnal Psikologi, $\quad 38(1), \quad 30-39$. https://doi.org/10.22146/jpsi.7662

Nowell, B., \& Boyd, N. M. (2014). Sense of community responsibility in community collaboratives: Advancing a theory of community as resource and responsibility. American Journal of Community Psychology, 54(3-4), 229242. https://doi.org/10.1007/s10464014-9667-x

Nurmuharimah, S. (2007). Get smart pendidikan kewarganegaraan. Grafindo Media Pratama.

Orford, J. (2008). Community psychology; Challenges, controversies, and emerging consensus. John Wiley \& Sons, Ltd.

Rappaport, J. (1981). In praise of paradox: A social policy of empowerment over prevention. American Journal of Community Psychology, 9, 1-25. https://doi.org/10.1007/BF00896357

Rezeky, S. M., Pandjaitan, N. K., \& Sjaf, S. (2018). Sistem nilai dan resiliensi komunitas dalam pengelolaan Rawa Lebak. Sodality, 6(3), 220-227. https://doi.org/10.22500/sodality.v6i3. 22482

Ridho, R. (2020, 24 Desember). Pandemi covid-19, angka kriminalitas meningkat, kecelakaan lalu lintas menurun. Kompas.com https://regional.kompas.com/read/2020 /12/24/06351531/pandemi-covid-19angka-kriminalitas-meningkatkecelakaan-lalu-lintasmenurun?page $=$ all
Terry, R., Townley, G., Brusilovskiy, E., \& Salzer, M. S. (2019). The influence of sense of community on the relationship between community participation and mental health for individuals with serious mental illnesses. Journal of Community Psychology, 47(1), 163175.

https://doi.org/10.1002/jcop.22115

The Food and Agriculture Organization. (2020). COVID-19 and the risk to food supply chains: How to respond?. (Policy Brief). http://www.fao.org/3/ca8388en/CA838 8EN.pdf

Theodori, G. L., \& Kyle, G. T. (2013). Community, place, and conservation. In W. P. Stewart, D. R. Williams, \& L. E. Kruger (Eds.), Place-based conservation: Perspectives from the social sciences (pp. 59-70). Springer.

Triana, A. A., \& Fauzi, A. M. (2020). Dampak pandemi corona virus diserse 19 terhadap meningkatnya kriminalitas pencurian sepeda motor di Surabaya. Syiah Kuala Law Journal, 4(3), 302309.

https://doi.org/10.24815/sklj.v4i3.1874 2

Triyasni. (2020). Infografis: Kejahatan meningkat saat pandemi corona. Liputan6.com.

https://www.liputan6.com/news/read/4 233905/infografis-kejahatanmeningkat-saat-pandemi-corona.

Van Breda, A. D. (2001). Resilience theory: A literature review (Research Report MPI/R/104/12/1/4). South African Military Psychological Institute. http://vanbreda.org/adrian/resilience/re silience_theory_review.pdf 
Wibowo, A. (2020, 25 April). Antisipasi isu keamanan dan ketertiban di tengah pandemi covid-19. Bnpb.go.id. https://bnpb.go.id/berita/antisipasi-isukeamanan-dan-ketertiban-di-tengahpandemi-covid-19

Windle, G., Bennett, K. M., \& Noyes, J. (2011). A methodological review of resilience measurement scales. Health and Quality of Life Outcomes, 9(8), 118. https://doi.org/10.1186/1477-75259-8

Yuriadi. (2018). Psikologi komunitas. AE Publishing. 